\title{
Retreat of Glaciar Tyndall, Patagonia, over the last half-century
}

\author{
Charles RAYMOND, ${ }^{1}$ Thomas A. NEUMANN, ${ }^{2}$ Eric RIGNOT, ${ }^{3}$ Keith ECHELMEYER, ${ }^{4}$ \\ Andrés RIVERA, ${ }^{5,6}$ Gino CASASSA ${ }^{5}$ \\ ${ }^{1}$ Department of Earth and Space Sciences, University of Washington, Seattle, Washington 98195-1310, USA \\ E-mail: charlie@ess.washington.edu \\ ${ }^{2}$ Department of Geology, University of Vermont, Burlington, Vermont 05405-0122, USA \\ ${ }^{3}$ Jet Propulsion Laboratory, California Institute of Technology, 4800 Oak Grove Drive, Pasadena, California 91109-8099, USA \\ ${ }^{4}$ University of Alaska Fairbanks, Fairbanks, Alaska 99775-7320, USA \\ ${ }^{5}$ Centro de Estudios Científicos de Valdivia, Av. Arturo Prat 514, Valdivia, Chile \\ ${ }^{6}$ Departamento de Geografía, Av. Marcoleta 250, Universidad de Chile, Santiago, Chile
}

\begin{abstract}
We report measurements of ice surface elevation, ice thickness and surface area for Glaciar Tyndall, Patagonia, made in 1999-2002. The measurements, together with previously published observations, show acceleration over the last few decades of the rates of thinning and retreat of the main calving front. The acceleration of shrinkage appears to be driven by a combination of climate and feedback processes, the dominant feedback being increased melting associated with lowering of the glacier surface (elevation feedback). The melting capacity in the main terminus lake is now too small to be a major factor accelerating the retreat. The glacier bed has low slope and remains below the elevation of the lake spillway for $>14 \mathrm{~km}$ upstream from the 2000 calving front, indicating the potential for extensive retreat under the influence of strong elevation feedback and increasing interaction with the lake as it enlarges.
\end{abstract}

\section{INTRODUCTION}

Hielo Patagónico Norte and Sur (northern and southern Patagonia icefields) and associated glaciers draining them comprise one of the most extensive concentrations of nonpolar ice (Meier, 1984; Dyurgerov and Meier, 1997). The glaciers are changing rapidly with essentially universal retreat of termini (Aniya and others, 2000). Most direct measurements of the mass balance, thickness and speed have been restricted to the near-terminus areas of a few glaciers for only short intervals during the summer. There is little information from the interior of the icefields. (See Casassa and others (2002) for a recent discussion.) Aniya (1999) and Rivera and others (2002) have made rough estimates of the rate of total ice volume loss from Patagonia on the basis of these measurements, but with wide error limits. Rignot and others (2003) have recently computed the mass balance of the Patagonian icefields based on comparison of 2000 Shuttle Radar Topography Mission (SRTM) data with Chilean and Argentine maps from earlier decades. Most of the large glaciers terminate at calving fronts in fjords or lakes, which complicates the assessment of future response to climate.

This paper examines Glaciar Tyndall (Fig. 1), which is one of the southernmost large glaciers draining Hielo Patagónico Sur. Over the last half-century, Glaciar Tyndall has been thinning and retreating in an enlarging terminus lake that formed in about 1940 as the glacier began to recede from neoglacial moraines (Naruse and others, 1987; Aniya, 1995; Nishida and others, 1995; Aniya and others, 1997, 2000; Rivera and Casassa, 2004). We report recent measurements of thickness and terminus position (19992002) and synthesize an extended record by combining these with previously published information available from as far back as 1944. We present the first measurements of ice thickness over the center of the glacier and half of its width in two cross-sections. We model ice flow in one of the

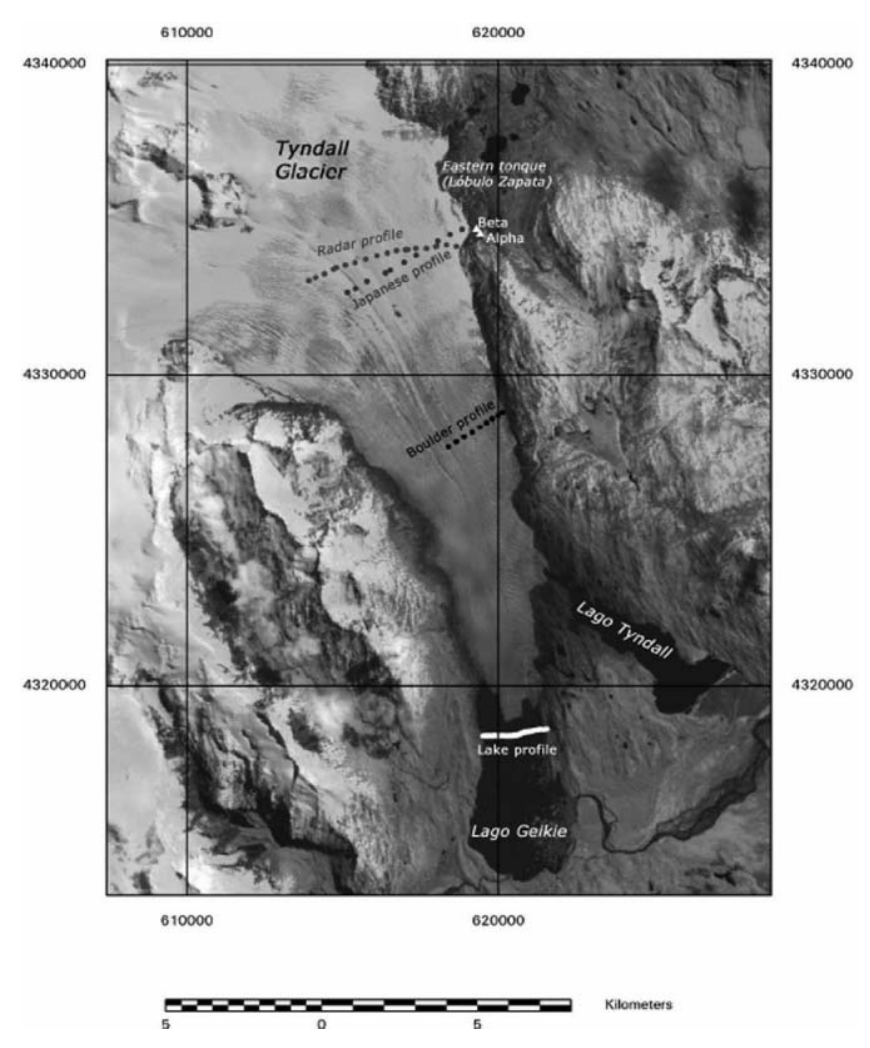

Fig. 1. Landsat Enhanced Thematic Mapper Plus (ETM+) image of Glaciar Tyndall, 27 October 2000, showing Lago Geikie, Lago Tyndall and the Eastern tongue. Lines show locations of the Japanese, Boulder and Lake Profiles discussed in this paper. Locations of other coverage from satellite (Rignot and others, 2003; Rivera and Casassa, 2004) and profiling in Lago Geikie (personal communication from B. Hallet) are not shown. Coordinates are UTM Zone 18 South. 


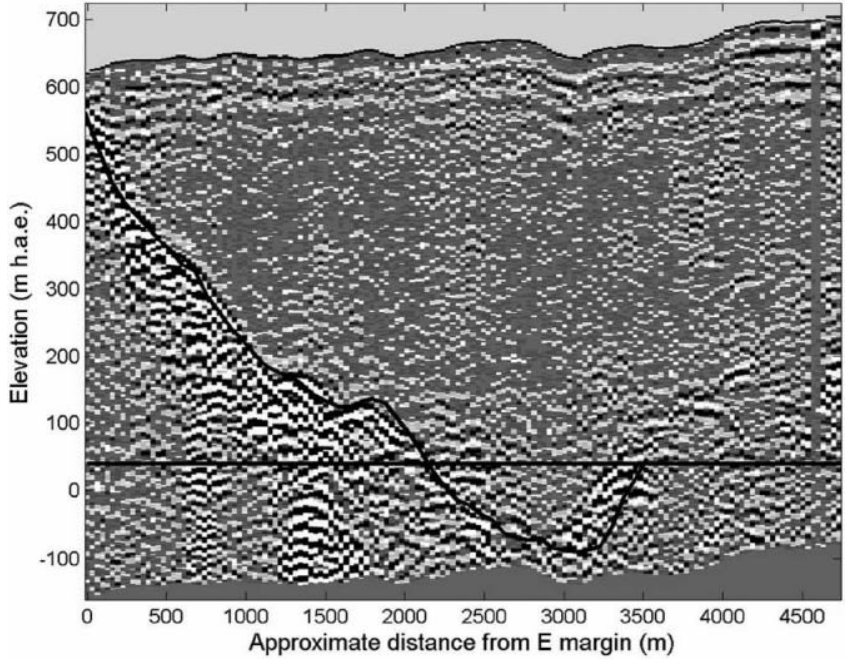

Fig. 2. Cross-section revealed by radio-echo traverse near the Japanese Profile (Fig. 1) with a $2 \mathrm{MHz}$ impulse, ice-penetrating radar with lightweight digital recording system deployed on foot with approximately $30 \mathrm{~m}$ spacing of measurements. The black curve is the bed estimated from two-dimensional migration of the data shown in the image. The surface elevation is based on GPS surveying. The horizontal line gives the approximate spillway elevation in the terminus lake. UTM Zone 18 South coordinates for the end points of the profile on the surface are $(4334159 \mathrm{~m} \mathrm{~N}$, $618644 \mathrm{~m} \mathrm{E}$ ) and (4333 $056 \mathrm{~m} \mathrm{~N}, 613920 \mathrm{mE})$.

cross-sections to assess controls on the motion on the basis of the limited velocity measurements now available. The ice-thickness measurements show that the ice base is lower than the outlet elevation of the terminus lake for $>14 \mathrm{~km}$ upstream from the 2000 terminus, which raises the issue of a catastrophic retreat up an expanding lake. We provide a simple model to assess the present influence of the lake on the course of the retreat.

\section{GEOMETRY AND MOTION OF GLACIAR TYNDALL}

Nishida and others (1995) give the following information for 1993 conditions: glacier length $32 \mathrm{~km}$, ablation area $118 \mathrm{~km}^{2}$ (about $16-22 \mathrm{~km}$ long and $3.5-10 \mathrm{~km}$ wide), accumulation area $219 \mathrm{~km}^{2}$, accumulation-area ratio (AAR) 0.65 and equilibrium-line altitude (ELA) $900 \mathrm{~m}$. The primary features are shown in Figure 1. The glacier terminates in a $2 \mathrm{~km}$ wide calving ice front in Lago Geikie. This lake has a spillway elevation of about $30 \mathrm{~m}$ a.s.l., which is about $40 \mathrm{~m}$ height above the World Geodetic System 1984 (WGS84) ellipsoid (referred to here as h.a.e.). The actual lake level varies because of obstruction of the outlet by icebergs. The glacier also calves into Lago Tyndall, a smaller lake on the left margin of the glacier northeast of Lago Geikie. Just below the equilibrium line the glacier spills over the ridge forming its left margin, extending a short tongue into an adjacent valley. Following Rivera and Casassa (2004), we call this the 'Eastern tongue' (also known as Lóbulo Zapata).

Most measurements have focused on a partial crossprofile established in 1985 by Naruse and others (1987) about $200 \mathrm{~m}$ below the ELA close to $700 \mathrm{ma.s.l}$. (710 m h.a.e.) and $14 \mathrm{~km}$ from the 2000 terminus location. We call it the 'Japanese Profile' (Fig. 1). The mean surface slope between the Japanese Profile and the terminus was about 0.041 .

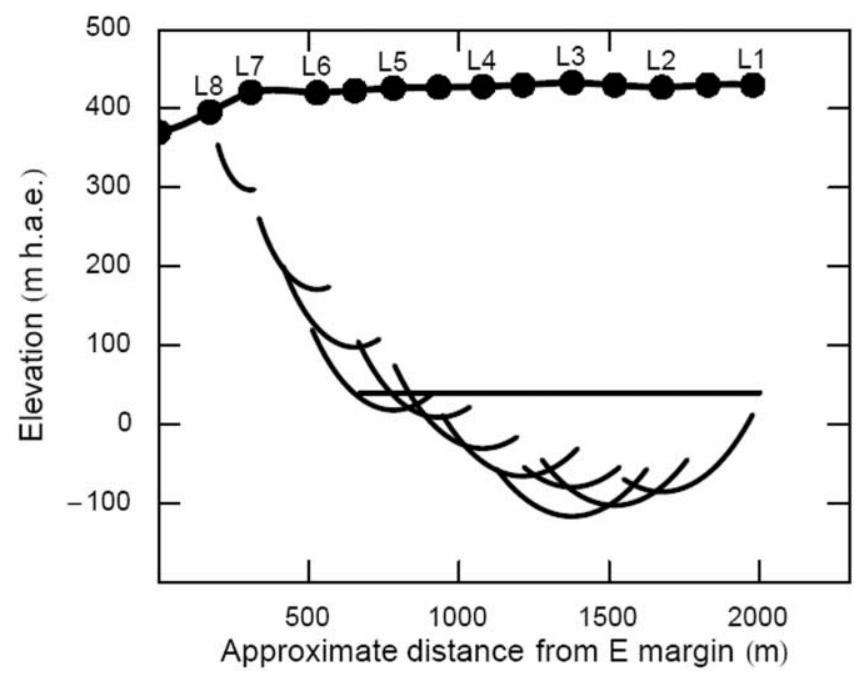

Fig. 3. Radar-bed return times converted to distance along the Boulder Profile (Fig. 1) using a $2 \mathrm{MHz}$ impulse, ice-penetrating radar deployed on foot with approximately $135 \mathrm{~m}$ spacing of measurements and manual recording of travel time using the receiver oscilloscope cursors. The envelope of migration ellipses gives the approximate profile of the bed. The surface elevation is based on GPS surveying. Coordinates of labeled points are given in Table 2. The horizontal line gives the approximate spillway elevation in the terminus lake.

Casassa (1992) and Casassa and Rivera (1998) measured ice thickness along the Japanese Profile, progressing out from the east margin until the thickness exceeded the $650 \mathrm{~m}$ detection limit of their radar system. We returned in 1999 to probe deeper with a more powerful transmitter. Results are shown in Figure 2, which shows a 1999 center thickness of $740 \mathrm{~m}$. In 2002 we measured another profile at about $420 \mathrm{~m}$ a.s.l. (430 $\mathrm{m}$ h.a.e.), and $5 \mathrm{~km}$ down-glacier from the Japanese Profile, that we call the 'Boulder Profile' (Fig. 1). Figure 3 shows the results; the 2002 center thickness was about $530 \mathrm{~m}$. Both profiles are restricted to the east half of the complete cross-section because of extensive crevassing to the west. However, the deepest part of the valley crosssection is revealed in each case to be within about $10 \mathrm{~m}$ of $-100 \mathrm{~m}$ a.s.l. ( $-90 \mathrm{~m}$ h.a.e.). The center bed profile, therefore, on average slopes back from the neoglacial terminus near the outlet of Lago Geikie all of the way upstream past the Japanese Profile.

Bathymetry carried out in 2001 in Lago Geikie by B. Hallet (unpublished data, 2001) showed maximum water depth exceeding $400 \mathrm{~m}$ (the detection limit of the sounder), with such depths restricted to a relatively small area. Here we show one cross-profile (Fig. 4) about $1 \mathrm{~km}$ from the 2001 terminus (Fig. 1), which shows a maximum depth of about $330 \mathrm{~m}$ with the bed at about $-310 \mathrm{~m}$ a.s.l. $(-300 \mathrm{~m}$ h.a.e. $)$.

Available measurements of ice motion are concentrated in the vicinity of the Japanese Profile, and they are restricted to short intervals during melt seasons. Speed in the center was about $700 \mathrm{ma}^{-1}$ during November/December 1985 (Naruse and others, 1987), $550 \pm 150 \mathrm{~m} \mathrm{a}^{-1}$ in November 1995 (Rignot, unpublished work based on synthetic aperture radar interferometry (InSAR)) and about $350 \pm 10 \mathrm{~m} \mathrm{a}^{-1}$ from 15 March to 20 March 2002 (from our global positioning system (GPS) measurements). A large seasonal variability in speed precludes any conclusions 


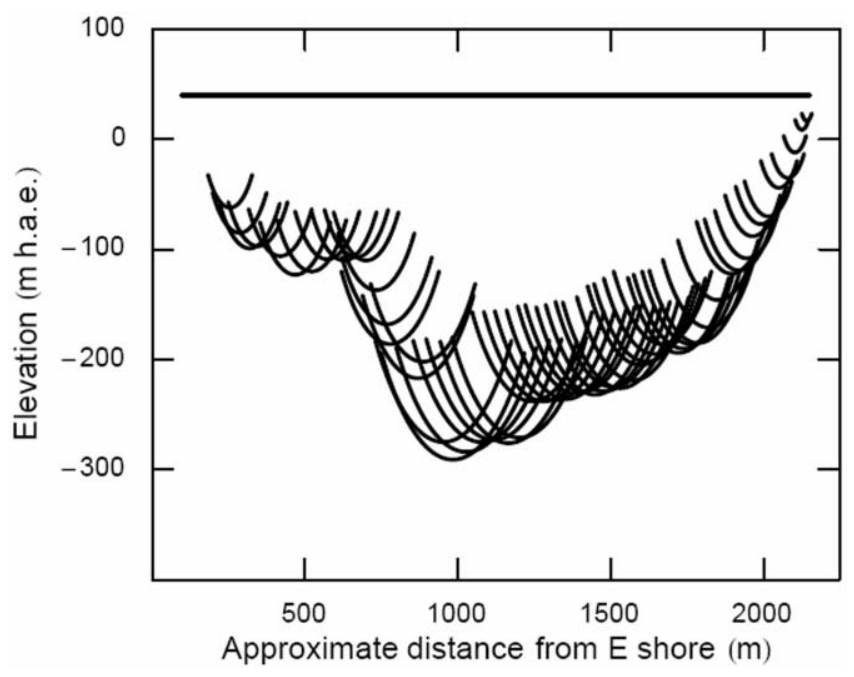

Fig. 4. Cross-section of the bed of Lago Geikie in the Lake Profile (Fig. 1) as determined with an acoustic sounder deployed in a small motor boat. UTM Zone 18 south coordinates for the end points of the profile on the surface are $(4318595 \mathrm{~m} \mathrm{~N}, 621428 \mathrm{mE})$ and $(4318383 \mathrm{~m} \mathrm{~N}, 619584 \mathrm{mE})$. The horizontal line shows the lake surface. These data are the most relevant for this paper from a larger set of sounding data taken by B. Hallet that will be published separately.

about longer-term trends in speed from these short-interval measurements. Measurements near the margin also show considerable temporal variability (Kadota and others, 1992; Nishida and others, 1995). The only long-term speed measurement that we have is near the center of the Boulder Profile (Fig. 1), based on a rock marker surveyed in March 2000 found and resurveyed in March 2002 to reveal a 2 year average speed of $323 \pm 10 \mathrm{ma}^{-1}$.

A theoretical ice-flow speed was calculated in the Japanese Profile cross-section (Fig. 2) using finite-element methods assuming Glen's flow law for temperate ice (Paterson, 1994, table $5.2 ; \dot{\varepsilon}=A \tau^{n}$ with $A=6.8 \times 10^{-15} \mathrm{~s}^{-1} \mathrm{kPa}^{-3}$ and $n=3$ ), no basal slip, ice density $0.9 \mathrm{Mg} \mathrm{m}^{-3}$, surface slope 0.03 and rectilinear flow (Nye, 1965). The calculation predicts a maximum central speed of $243 \mathrm{ma}^{-1}$, a width-averaged speed of $130 \mathrm{~m} \mathrm{a}^{-1}$ and a cross-section averaged speed of $126 \mathrm{~m} \mathrm{a}^{-1}$. The value of $A$ given by Paterson is an average of laboratory experiments and in situ measurements on glaciers, with experiments tending to be higher than in situ results. On this basis, the predicted deformational velocities are more likely to be overestimated than underestimated. The considerable excess of measured surface speed over the prediction, together with the measured short-term variability, indicates that there is a large, time-varying contribution from basal motion of several hundred meters per year.

Recently exposed areas of the bed of Glaciar Tyndall are hard rock, generally clean, striated and locally polished. Although we are not able to quantify absolute bed reflectivity with our radar, we can discern that returns from the base of Glaciar Tyndall are considerably less than those found with the same system at equivalent depth from the bed of Black Rapids Glacier, Alaska, USA, which is till-laden (Truffer and others, 1999) and consequently highly reflective. These observations together suggest a hard bed beneath the ice of Glaciar Tyndall. Thus, we speculate that the high, variable rates of basal motion at Glaciar Tyndall may be controlled by hard bed sliding processes.

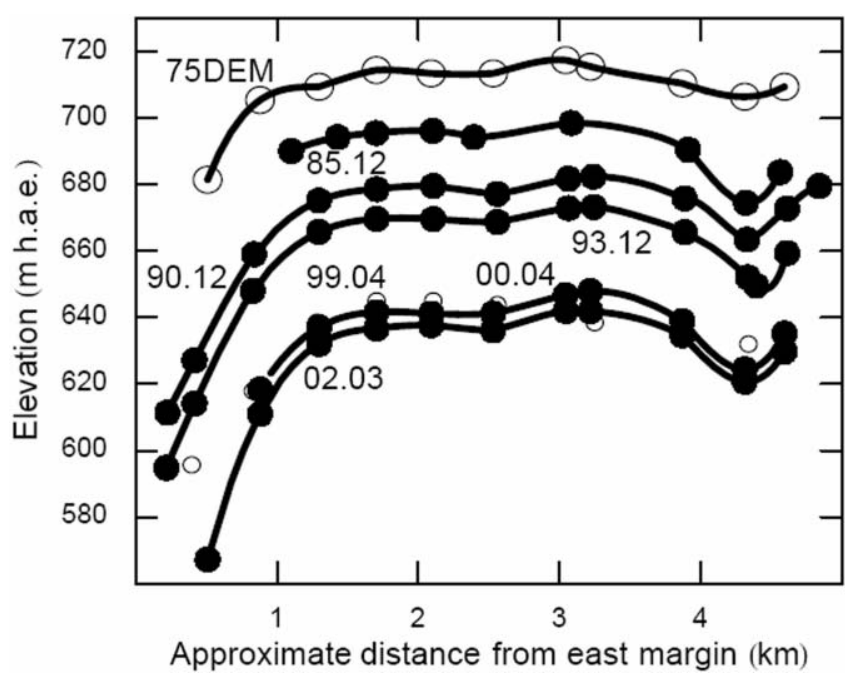

Fig. 5. Elevation of ice surface along the Japanese Profile for dates indicated by year.month, based on a 1975 map (Kadota and others, 1992), compilation for 1985, 1990 and 1993 by Nishida and others (1995), and our data for 2000 and 2002. Surveying in 1999, shown as open circles 99.04 (Rivera and Casassa, 2004), do not exactly track the same line as the other measurements and are not used in the elevation change analysis here. See Appendix for discussion of datum adjustments.

\section{SHRINKAGE}

Surface elevation has been determined in the vicinity of the Japanese Profile for 1985 (Naruse and others, 1987), 1990 (Kadota and others, 1992), 1993 (Nishida and others, 1995) and 1999 (Rivera and Casassa, 2004) by angle and distance measurements to lines of markers from stations on the east valley wall (Alpha and Beta in Fig. 1) established by Naruse and others (1987). Nishida and others (1995) summarize the results for 1985, 1990 and 1993 for surface elevation along a common line defined by Kadota and others (1992). Kadota and others estimated the 1975 elevation using a 1:25000 map derived from photogrammetric analysis of March 1975 aerial photographs by the Chilean Air Force using Alpha as the control, thus tying the 1975 map elevation to the 1985, 1990 and 1993 measurements without ambiguity. A digital map (Rignot and others, 2003) based on a 1975 map compiled by Instituto Geográfico Militar of Chile (IGMCh) gives consistent results, when differences in datum assumptions are taken into account. We determined elevations along the Japanese Profile in 2000 and 2002 using GPS methods. Details and tabular results are given in the Appendix, which also discusses reduction of earlier measurements to a common WGS84 ellipsoid datum. The combined results outlined above are shown in Figure 5. Thinning in the Japanese Profile from 1975 to 1993, identified by Kadota and others (1992) and Nishida and others (1995), is continuing.

Figure 6 shows the mean thinning rates for the approximate decade intervals $1975-85\left(1.7 \mathrm{~m} \mathrm{a}^{-1}\right), \quad 1985-93$ $\left(3.3 \mathrm{~m} \mathrm{a}^{-1}\right)$ and $1993-2002\left(3.6 \mathrm{ma}^{-1}\right)$ derived from the markers in the central part of the glacier. Markers on steep slopes within $1 \mathrm{~km}$ of the east margin were not included in the calculated surface elevation change, to avoid errors caused by slight differences in the horizontal position.

In 1993 Aniya and others (1997) identified the location of the 1945 margin on the valley wall near Alpha using 


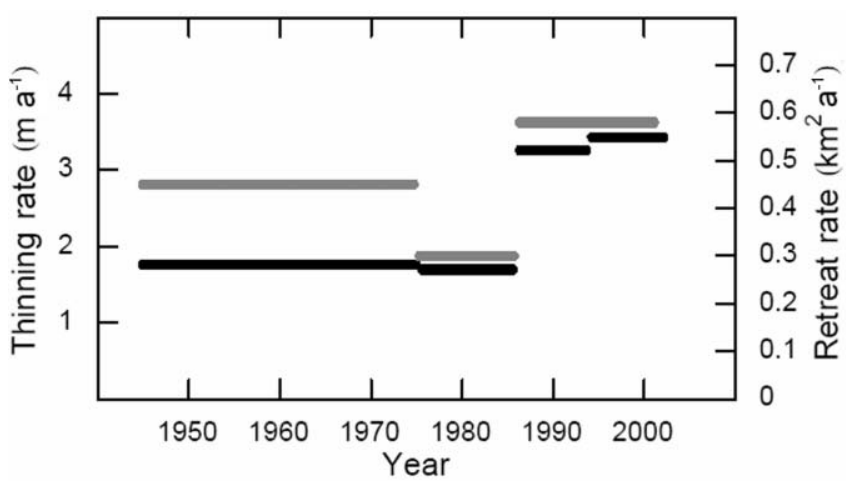

Fig. 6. Rate of thinning at the Japanese Profile (black bar, left axis) and rate of grounded-ice area decrease (grey bar, right axis) averaged over selected decadal or longer time intervals synthesized from published data and our measurements.

Trimetrogon photography from austral summer 1944/45, and estimated a mean rate of thinning at the east margin of $2.0 \mathrm{ma}^{-1}$ from 1945-93. Based on this information and results from 1975 and 1993, we estimate a mean thinning rate of $1.8 \mathrm{~m} \mathrm{a}^{-1}$ for 1945-75. We show 1945-75 in Figure 6 for comparison with rates during the last three decades. We also found long-term mean thinning rates of $2.3 \mathrm{~m} \mathrm{a}^{-1}$ for 1945-2002 and $2.8 \mathrm{~m} \mathrm{a}^{-1}$ for 1975-2002, which for simplicity we do not show in Figure 6.

Surface elevation was measured on the Boulder Profile in 2002 by the same method as described for the Japanese Profile, with results tabulated in the Appendix. The 1975 IGMCh map and our 2002 GPS survey results indicate a mean thinning rate of $3.2 \pm 0.6 \mathrm{~m} \mathrm{a}^{-1}$ from 1975 to 2002 for the Boulder Profile location. That is somewhat larger than for the Japanese Profile over the same time interval and consistent with more pronounced thinning toward the main terminus, as is generally characteristic of retreating glaciers. Unfortunately, measurements are insufficient to examine thinning vs time in the Boulder Profile.

Naruse and others (1987) and Aniya and others (1997) used maps, aerial photographs and satellite imagery from 1944/45, March 1975, January 1986 and February 1994 to estimate rates of retreat through Lago Geikie over the intervening time intervals. From $1944 / 45$ to 2000, the glacier retreated about $5 \mathrm{~km}$ in Lago Geikie. Retreat through Lago Tyndall has also been substantial, but the calving front there has been narrow (about $0.2 \mathrm{~km}$ ) and relatively stable in position since about 1975 . Retreat in the area between these two lakes and of the Eastern tongue has been up to about $2 \mathrm{~km}$ in some locations, with calving restricted to local small lakes and transient. Rivera and Casassa (2004) used Landsat ETM+ imagery from October 2000 and earlier information to synthesize a full record of frontal retreat. Figure 6 shows their results for rate of total area decrease in available intervals from 1945 to 2000 (Rivera and Casassa, 2004, table 11, figs 6 and 7). Examining total area avoids problems associated with the complex and variable outlines of the calving fronts and includes substantial retreat of the terrestrial margins. In view of the probable erratic nature of the retreat in Lago Geikie, one example being a very rapid retreat of about $0.7 \mathrm{~km}$ from the time of October 2000 imagery to a March 2001 visit to the lake, only average rates over decadal or longer intervals are shown.
The mean thinning rate over the last few decades at the Japanese Profile (about $3 \mathrm{~m} \mathrm{a}^{-1}$ ) is close to a recent estimate of an average for 55 Patagonian glaciers at the same altitude $(600 \mathrm{~m})$ (Rignot and others, 2003, fig. 2). Similarly, area reduction on Glaciar Tyndall (about $0.5 \mathrm{~km}^{2} \mathrm{a}^{-1}$ ) is not extraordinary amongst large Patagonian glaciers (Aniya and others, 2000; Aniya, 2001). Although Glaciar Tyndall appears fairly average, it is not clearly representative or typical, as there is a very large spread in Patagonian glacier trends. Indeed, thinning rates exceeding $10 \mathrm{~m} \mathrm{a}^{-1}$ and area reduction rates exceeding $1 \mathrm{~km}^{2} \mathrm{a}^{-1}$ are known (Skvarca and others, 1995; Aniya and others, 2000), while the thickness of Glaciar Perito Moreno has been relatively stable, with gradual and fluctuating changes (Skvarca and others, 2004). The most compelling feature of the record from Glaciar Tyndall is a clear acceleration of shrinkage in the last few decades, with both thinning and area reduction following a similar pattern with no clear lag or lead of one over the other (Fig. 6).

\section{DRIVING THE SHRINKAGE}

We now address factors responsible for the increase in shrinkage rate since about 1975 . In particular, we focus on the relative importance of direct climate forcing compared to geometry-change feedbacks associated with surface elevation drop, reduced glacier area and loss of ice to the lakes. The substantial drop in surface elevation suggests that elevation feedback is an important consideration (Bodvarsson, 1955; Weertman, 1961; Oerlemans, 1981). Clearly, an important question for Glaciar Tyndall and most of the other large Patagonian glaciers is what role termination in water could play in their shrinkage (Meier and Post, 1987).

A standard approach would be to consider the glacier mass balance with inclusion of ice loss by calving into the lakes. Instead, we choose to consider the ice mass balance in the combined glacier-lake system (Fig. 7). This approach has the advantage that we do not need to explicitly consider ice motion dynamics or calving, about which we have little information. Ice motion and calving only redistribute ice within the glacier-lake system; they do not cause ice loss. We do, though, need to explicitly consider heat balance of the lakes (Björnsson and others, 2000; Landl and others, 2003). Calved ice does not flow out of the lakes, so in situ melting is the only way to remove it. Because the lakes are relatively small without significant water inflow other than from the glacier, the situation may be different to that found for calving into very large lakes, estuaries or the sea, where the heat reservoir for melting is effectively unlimited and icebergs can float away.

Calving of ice into Lago Geikie is vigorous across a wide ice front retreating in deep water, and icebergs usually cover a significant part of the lake surface. Calving of ice into Lago Tyndall has declined in recent decades and is now relatively subdued and through a narrow, shallow connection between the glacier and the lake. Therefore, we view the Lago Tyndall front as part of the terrestrial margin.

For consideration of the heat and ice mass balance in the combined glacier-lake system (Fig. 7), we denote glacier area as $A_{\mathrm{g}}$ and lake area (Lago Geikie) as $A_{1}$. The total area is $A_{\mathrm{g}}+A_{\mathrm{l}}$. For our purposes, we consider the area of floating ice including icebergs to be part of $A_{\mathrm{g}}$ rather than $A_{\uparrow}$. We let $h$ represent the surface height varying over area $A_{\mathrm{g}}$. 
To examine the acceleration in shrinkage rate we estimate the change in average mass-balance rate per unit area of glacier $A_{\mathrm{g}}$ denoted as $\Delta\langle b\rangle$, where $\Delta\langle b\rangle$ is measured relative to a reference climate and geometry $\left(A_{g}, A_{l}\right.$ and $\left.h\right)$. We take the reference geometry given by the 1975 map $\left(A_{\mathrm{g}}=319 \mathrm{~km}^{2}, A_{\mathrm{l}}=10 \mathrm{~km}^{2}\right)$. Although the change in $h$ may vary over $A_{g}$, we consider a single representative change $\Delta h$ relative to 1975 . There are four contributions to $\Delta\langle b\rangle$ : direct climate forcing defined as $\Delta\langle b\rangle$ that would be experienced by the constant reference geometry, and geometrical feedbacks associated with changes in elevation $\Delta h$, in glacier area $\Delta A_{\mathrm{g}}$ and in lake area $\Delta A_{\mathrm{l}}$. The following procedure is adapted to the limited data now available and the present lake condition.

The first three contributions are long-established considerations for glaciers, and we adopt notation similar to Elsberg and others (2001). Direct climate forcing is estimated in terms of ELA in the form $-G_{\mathrm{e}} \Delta \mathrm{ELA}$; elevation feedback is $G_{\mathrm{h}} \Delta h$; and glacier area feedback is $b_{\mathrm{t}} \Delta A_{\mathrm{g}} / A_{\mathrm{g}}$ where $b_{\mathrm{t}}$ is the terminus ablation rate (a negative number). We further evaluate $b_{\mathrm{t}}$ as $b_{\mathrm{t}}=-G_{\mathrm{t}} H$, where $H$ is the difference in elevation between the ELA and the terminus (about $850 \mathrm{~m}$ ). $G_{\mathrm{e}}, G_{\mathrm{h}}$ and $G_{\mathrm{t}}$ are scaling factors, all with dimensions of time ${ }^{-1}$, associated with effective vertical gradients in ice-equivalent-thickness balance rate. For example, $G_{t}$ is the mean vertical gradient of balance rate between the equilibrium line and the terminus. In principle, these factors could be chosen for optimal representation of each of the three contributions on the basis of measurements of the mass-balance distribution over time. In the absence of such measurements, we make the reasonable assumption that $G_{\mathrm{e}}=G_{\mathrm{h}}=G_{\mathrm{t}} \equiv G$. One circumstance where this relation would hold is a balance rate gradient independent of altitude and a smooth longitudinal profile of the glacier surface. More generally, it is not likely to be grossly wrong.

The fourth contribution, lake area feedback, is described by $b_{l} \Delta A_{1} / A_{\mathrm{g}}$ where $b_{\mathrm{l}}$ is the melting that would be caused by the net heat absorbed from the atmosphere by a unit area of the lake surface (expressed as a negative number). This description involves the following assumptions. First, negligible ice flows out of the lake, which is reasonable in view of the shallow outlet and no apparent ice floating downstream. Second, water introduced to the lake from glacier run-off and iceberg melting is at the melting point, and carries no heat for melting. Third, all of the heat entering expanded lake area $\Delta A_{\mathrm{l}}$ is used to melt ice floating in the lake. (This assumption is reasonable, since the water flowing out of the lake typically flows through an iceberg jam and exits at freezing point without carrying heat for melting away.) Fourth, flow of warm water into the lake from the surrounding watershed is negligible. (We do not have data about water influx or its temperature to verify this assumption. We do know that the creeks flowing into the lake supply only a small fraction of the water input to the lake, the major amount coming from cold glacier run-off. Furthermore, retreat over the last few decades and into the near future does not introduce substantial new water input, since water from the valley sides tends to be routed behind moraines and along benches on the west, and there is limited watershed area on the east.)

To further simplify our considerations of the lake, we scale $b_{\mathrm{l}}$ to $b_{\mathrm{t}}$ with a scaling $E$ so that $b_{\mathrm{l}}=E b_{\mathrm{t}}$, which is founded on the notion that meteorological conditions above the terminal ice and lake surfaces should be related. A lake

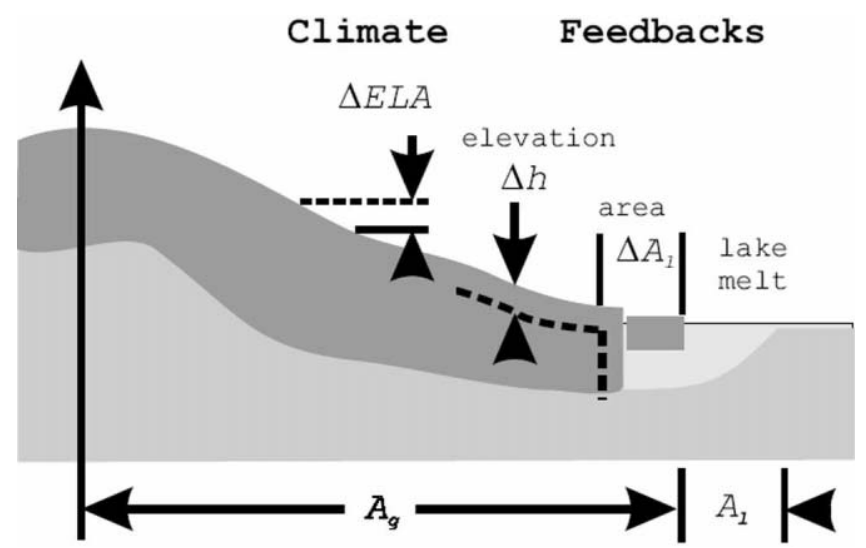

Fig. 7. Schematic representation of climate forcing by change in equilibrium-line elevation $\triangle E L A$ and feedbacks associated with changes in surface elevation $\Delta h$, glacier area $\Delta A_{\mathrm{g}}$ and lake area $\Delta A_{\text {l. }}$.

surface very close to the freezing point is indicated by the typical, half-coverage of the lake by icebergs, negative buoyancy of warm water near freezing and observation of the formation of a skin of ice on the free lake surface during a cold night after a warm day. The thermal situation may be much like that measured in the somewhat similar proglacial Lago Nef (Warren and others, 2001), where water temperature is within $0.5^{\circ} \mathrm{C}$ of freezing. For water at $0^{\circ} \mathrm{C}$, the longwave radiation balance of lake and adjacent ice surfaces should be nearly the same. Turbulent fluxes could be slightly different because of different roughness (e.g. Landl and others, 2003), but this is not likely to be a dominant effect. The main difference in heat balance should come from the lower albedo of the water compared to the ice surface, giving larger net shortwave radiation capture in the lake than in the ice. Then $E$ can be estimated by extrapolating the dependence of ablation rate on albedo from typical terminus albedo controlling $b_{\mathrm{t}}$ to the albedo of a water surface controlling $b_{\mid}$. We estimate $E=1.6-1.7$ from dependence of ablation rate on albedo found by Takeuchi and others (1995, p. 49) for mid-summer intervals of 1 week on Glaciar Tyndall and 2 weeks on Glaciar Moreno, assuming albedos of 0.40 for the terminus ice and 0.06 for the lake-water surface.

Combining the four contributions expressed as above and factoring out $G$ gives

$$
\Delta\langle b\rangle=G\left(-\Delta \mathrm{ELA}+\Delta h-H \Delta A_{g} / A_{g}-E H \Delta A_{\mathrm{l}} / A_{\mathrm{g}}\right) .
$$

We can estimate the relative importance of the four contributions to $\Delta\langle b\rangle$ by examining the four heights in the parentheses on the righthand side of Equation (1). We focus on the changes 1975-2000 for which Rivera and Casassa (2004) give information that indicates: $\Delta A_{l}=3.1 \mathrm{~km}^{2}$ (assuming that the typical area of iceberg coverage did not change) and $\Delta A_{\mathrm{g}}=-11.4 \mathrm{~km}^{2}\left(-3.1 \mathrm{~km}^{2}\right.$ in Lago Geikie, $-0.3 \mathrm{~km}^{2}$ in Lago Tyndall, $-4.1 \mathrm{~km}^{2}$ along the terrestrial margin between the lakes and $-3.8 \mathrm{~km}^{2}$ for the Eastern tongue).

For climate forcing we adopt a plausible increase in temperature of about $0.3^{\circ} \mathrm{C}$ that occurred since 1975 as indicated by the US National Centers for Environmental Prediction/US National Center for Atmospheric Research (NCEP/NCAR) re-analysis database (Rasmussen and others, in press) and an atmospheric lapse rate of $6^{\circ} \mathrm{C} \mathrm{km}^{-1}$ which together estimate $-\Delta \mathrm{ELA}=-50 \mathrm{~m}$. The measurements 
(section 3) give $+\Delta h=-86 \mathrm{~m}$ at the Japanese Profile, $-H \Delta A_{\mathrm{g}} / A_{\mathrm{g}}=+30 \mathrm{~m}$ and $-E H \Delta A_{\mathrm{l}} / A_{\mathrm{g}}=-13 \mathrm{~m}$. From the relative sizes of the three feedback heights, we see that elevation feedback $(-86 \mathrm{~m})$ is the largest in magnitude. The area feedback $(+30 \mathrm{~m})$ is partly cancelled by increasing lake area $(-13 \mathrm{~m})$. The combined area feedback for glacier and lake $(+17 \mathrm{~m})$ is much less than the elevation feedback $(-86 \mathrm{~m})$. Alone the effect of melting in the lake $(-13 \mathrm{~m})$ is important, but not a dominating influence. The combined feedback $(-69 \mathrm{~m})$ reinforces the climate forcing $(-50 \mathrm{~m})$ and is larger in magnitude.

To estimate the different contributions to total mass balance (Equation (1)), we need to evaluate $G$. Naruse and others $\left(1995\right.$, p. 301) found a balance gradient of $0.015 \mathrm{a}^{-1}$ on Glaciar Moreno. On Glaciar Tyndall, this gradient predicts $b_{\mathrm{t}}=-G_{\mathrm{t}} H=-13 \mathrm{~m} \mathrm{a}^{-1}$, which is reasonable. Accepting this value for $G$ on Glaciar Tyndall yields the following results for the four terms on the righthand side of Equation (1): climate change $-0.7 \mathrm{~m} \mathrm{a}^{-1}$, elevation feedback $-1.3 \mathrm{~m} \mathrm{a}^{-1}$, glacier area feedback $+0.5 \mathrm{~m} \mathrm{a}^{-1}$ and lake area feedback $-0.2 \mathrm{ma}^{-1}$. They sum to $-1.8 \mathrm{~m} \mathrm{a}^{-1}$, which estimates the change in balance rate for 2002 compared to 1975 averaged over $A_{\mathrm{g}}(\Delta\langle b\rangle)$ on the lefthand side of Equation (1).

\section{DISCUSSION}

The total change in balance rate for 1975-2002 estimated above $\left(-1.8 \mathrm{~m} \mathrm{a}^{-1}\right)$ is close to the increase in thinning rate at the Japanese Profile (about $2 \mathrm{ma}^{-1}$, from about $2 \mathrm{ma}^{-1}$ in 1975 to about $4 \mathrm{ma}^{-1}$ in 2002; Fig. 6). The balance rate estimate represents a glacier average including, in our development, iceberg area. The thinning rate at the Japanese Profile is subject to local climate, dynamics and margin changes such as in the Eastern tongue, which is not far off. Therefore, close equality should not necessarily be expected. Certainly, the agreement within $0.2 \mathrm{ma}^{-1}$ does not justify an expectation of similar accuracy for the individual terms on the righthand side of Equation (1), for which it is difficult to assign quantitative errors. To fully assess the individual terms, one must account for interannual variability in weather, spatial patterns of mass-balance and elevation change and relation to changing margin position. Nevertheless, we are confident that the relative sizes of distinctly different terms are correct, which enables us to identify dominant factors driving the retreat as in the previous section.

An important observation is that the net effect of the feedbacks is reinforcing and larger than the direct climate forcing. In the response to the warming climate of a typical mountain glacier with a terrestrial terminus on a fairly steep rock slope, negative climate forcing is compensated by area feedback associated with a reduction in ablation area. Elevation feedback may be of secondary importance and calving is not a consideration. For Glaciar Tyndall elevation feedback is now the primary feedback. Its main terminus area remains at the low elevation of Lago Geikie as it retreats. That forces substantial lowering of the upstream surface profile because of the high mean surface slope (about 0.04) associated with high basal shear stress (about $150 \mathrm{kPa}$ ) probably on a hard bed. That geometrical effect is now the most important aspect of the lake. Greater heat absorption for melting icebergs in an enlarged lake is secondary, even if calving were to accelerate.
An interesting speculation is why Lago Geikie is rarely, if ever, completely jammed with icebergs, given the potential large calving capacity of the deep terminal front $(>350 \mathrm{~m})$ and the limited melting capacity of the lake, which would further decrease with increased iceberg coverage. It suggests a fairly sensitive feedback between lake conditions and calving rate beyond near-terminus geometry (e.g. water depth) such that an increasing iceberg population can suppress calving. Since calving appears to stop at a less than fully jammed condition, the control is more probably water temperature (e.g. Warren and Kirkbride, 2003) than mechanical back-pressure from icebergs. Because of the negative thermal buoyancy of water near the freezing point, water warmed at the lake surface will sink to where it can form a heat reservoir interacting with the calving front (and icebergs) through circulation driven by horizontal density gradients (Funk and Röthlisberger, 1989). Thus, warming at the lake surface may not be a necessary feature of such feedback.

With additional enlargement of Lago Geikie, increased melting capacity would become a more important contribution to the acceleration of ice melt as long as the calving rate were also to increase. Once the melting capacity of the lake exceeds the capacity of calving to deliver ice, the lake surface can warm significantly above freezing. The ice melt in the lake would then be limited by delivery from calving. Consideration of the ice balance in the combined, glacier-lake system becomes less useful, and explicit treatment of the calving appears inescapable. If water temperature influences calving rate, consideration of heat balance in the lake would still be important, but the simplified analysis based on $0^{\circ} \mathrm{C}$ surface temperature would fail. This situation would likely arise in Lago Geikie, if the terminus were to retreat to the vicinity of the 'Boulder Profile' (Fig. 1), giving a larger lake area by roughly a factor of two and a narrower calving front in considerably shallower water (Fig. 3).

The surface profile above the present terminus in Lago Geikie is fairly steep, suggesting a rising bed from the deep waters $(350 \mathrm{~m})$ in the present lake, so a stabilizing effect of reduced calving in shallower water could possibly occur with considerably less retreat than to the Boulder Profile. On the other hand, the bed is well below the lake spillway level at least as far up-glacier as the Japanese Profile. Clearly, a forecast of both short- and long-term rates of retreat will depend heavily on more detailed information about bed geometry as well as the calving process into the lake and dynamic factors transferring ice from upstream to the calving front.

Our development of the ice-lake interaction is founded on the notion of two end-member regimes: melt-capacitylimited and calving-limited. Glaciar Tyndall is presently in the first of these regimes, which may be characteristic of the initial stages of recession of a glacier into a developing proglacial lake. Other examples of melt-capacity-limited lacustrine glaciers in Patagonia could be Glaciar Soler (Aniya and others, 2002) and Glaciar Nef (Warren and others, 2001), which now terminate in relatively small lakes. The many glaciers interacting with very large lakes on the east side of the icefields (examples of ones that have been studied are Upsala (Skvarca and others, 2003) and Moreno (Skvarca and others, 2004)) and the fjords on the west are probably calving-limited and demand a more complex analysis including calving explicitly. 


\section{CONCLUSION}

The acceleration in shrinkage rate of Glaciar Tyndall in the last few decades is driven by climate change and a combination of feedbacks. The total feedback reinforces the direct climate forcing. The most important reinforcing feedback is associated with increased ablation on a lowered surface (elevation feedback). The stabilizing feedback of decreasing glacier area (area feedback) is smaller in magnitude than the direct climate driving or the elevation feedback. In present circumstances, the melting potential in the lakes is limited because of their small size relative to the area of the glacier, which places an upper limit on the role of calving in accelerating retreat that is even smaller. A bed well below the lake spillway level for $>14 \mathrm{~km}$ up-glacier from the present front indicates the potential for an eventual large-scale retreat of the glacier.

\section{ACKNOWLEDGEMENTS}

This research was supported by US National Science Foundation grant No. INT-9802764, NASA contract No. 1215388 and Fondecyt (Chile) 7980057. Theodolite/EDM measurements made by $\mathrm{H}$. Lange in 1999 provided important information for relating recent GPS-based measurements to earlier optical surveying. We are grateful to B. Hallet and $\mathrm{H}$. Conway for providing sounding data from Lago Geikie prior to publication. Support from Universidad de Magallanes, Chile, in the form of field equipment and enthusiastic help from staff and students is acknowledged, particularly from C. Cardenas, M.A. Godoi and N. Lucero. Permission from Parque Nacional Torres del Paine and the efficient logistic organization of R. Traub (Trauko) made our field measurements possible. We appreciate comments from two reviewers and Scientific Editor K. Cuffey that helped us improve the final manuscript.

\section{REFERENCES}

Aniya, M. 1995. Holocene glacial chronology in Patagonia: Tyndall and Upsala glaciers. Arct. Alp. Res., 27(4), 311-322.

Aniya, M. 1999. Recent glacier variations of the Hielo Patagónicos, South America, and their contribution to sea-level change. Arct. Antarct. Alp. Res., 31(2), 165-173.

Aniya, M. 2001. Glacier variations of Hielo Patagónico Norte, Chilean Patagonia, since 1944/45, with special reference to variations between 1995/96 and 1999/2000. Bull. Glaciol. Res., 18, 55-63.

Aniya, M., H. Sato, R. Naruse, P. Skvarca and G. Casassa. 1997. Recent glacier variations in the Southern Patagonia Icefield, South America. Arct. Alp. Res., 29(1), 1-12.

Aniya, M., A.S. Dhakal, S. Park and R. Naruse. 2000. Variations of Patagonian glaciers, South America, using RADARSAT and Landsat images. Can. J. Remote Sensing, 26(6), 501-511.

Aniya, M., R. Naruse and S. Yamaguchi. 2002. Utilization of $6 \times$ $6 \mathrm{~cm}$ format vertical aerial photographs for repetitive mapping of surface morphology and measurement of flow velocities of a small glacier in a remote area: Glaciar Soler, Hielo Patagónico Norte, Chile. Ann. Glaciol., 34, 385-390.

Björnsson, H., F. Pálsson and S. Gudmundsson. 2000. Jökulsárlón at Breiðamerkursandur, Vatnajökull, Iceland: 20th century changes and future outlook. Jökull, 50, 1-18.

Böðvarsson, G. 1955. On the flow of ice-sheets and glaciers. Jökull, $5,1-8$.

Casassa, G. 1992. Radio-echo sounding of Glaciar Tyndall, southern Patagonia. Bull. Glacier Res., 10, 69-74.
Casassa, G. and A. Rivera. 1998. Sondaje de radar digital en el glaciar Tyndall, Patagonia. Anales Instituto de la Patagonia, 26, 129-135.

Casassa, G., A. Rivera, M. Aniya and R. Naruse. 2002. Current knowledge of the Southern Patagonia Icefield. In Casassa, G., F.V. Sepúlveda and R. Sinclair, eds. The Patagonian ice fields: a unique natural laboratory for environmental and climate change studies. New York, Kluwer Academic/Plenum Publishers, 67-83.

Dyurgerov, M.B. and M.F. Meier. 1997. Year-to-year fluctuations of global mass balance of small glaciers and their contribution to sea-level changes. Arct. Alp. Res., 29(4), 392-402.

Elsberg, D.H., W.D. Harrison, K.A. Echelmeyer and R.M. Krimmel. 2001. Quantifying the effects of climate and surface change on glacier mass balance. J. Glaciol., 47(159), 649-658.

Funk, M. and H. Röthlisberger. 1989. Forecasting the effects of a planned reservoir which will partially flood the tongue of Unteraargletscher in Switzerland. Ann. Glaciol., 13, 76-81.

Kadota, T., R. Naruse, P. Skvarca and M. Aniya. 1992. Ice flow and surface lowering of Glaciar Tyndall, southern Patagonia. Bull. Glacier Res., 10, 63-68.

Landl, B., H. Bjornsson and M. Kuhn. 2003. The energy balance of calved ice in Lake Jökulsarlón, Iceland. Arct. Antarct. Alp. Res., 35(4), 475-481.

Meier, M.F. 1984. Contribution of small glaciers to global sea level. Science, 226(4681), 1418-1421.

Meier, M.F. and A. Post. 1987. Fast tidewater glaciers. J. Geophys. Res., 92(B9), 9051-9058.

Naruse, R., H. Peña, M. Aniya and J. Inoue. 1987. Flow and surface structure of Glaciar Tyndall, the Southern Patagonia Icefield. Bull. Glacier Res., 4, 133-140.

Naruse, R., M. Aniya, P. Skvarca and G. Casassa. 1995. Recent variations of calving glaciers in Patagonia, South America, revealed by ground surveys, satellite-data analyses and numerical experiments. Ann. Glaciol., 21, 297-303.

Nishida, K., K. Satow, M. Aniya, G. Casassa and T. Kadota. 1995. Thickness change and flow of Glaciar Tyndall, Patagonia. Bull. Glacier Res., 13, 29-34.

Nye, J.F. 1965. The flow of a glacier in a channel of rectangular, elliptic or parabolic cross-section. J. Glaciol., 5(41), 661-690.

Oerlemans, J. 1981. Some basic experiments with a verticallyintegrated ice sheet model. Tellus, 33(1), 1-11.

Paterson, W.S.B. 1994. The physics of glaciers. Third edition. Oxford, etc., Elsevier.

Rasmussen, L.A., H. Conway and C.F. Raymond. In press. Influence of upper air conditions on the Patagonia icefields. Global Planet. Change.

Rignot, E., A. Rivera and G. Casassa. 2004. Contribution of the Patagonia icefields of South America to global sea level rise. Science, 302(5644), 434-437.

Rivera, A. and G. Casassa. 2004. Ice elevation, area and frontal changes of glaciers from Torres del Paine National Park, Southern Patagonia Icefield. Arct. Antarct. Alp. Res., 36(4), 379-389.

Rivera, A., C. Acuña, G. Casassa and F. Bown. 2002. Use of remotely-sensed and field data to estimate the contribution of Chilean glaciers to eustatic sea-level rise. Ann. Glaciol., 34, 367-372.

Skvarca, P., K. Satow, R. Naruse and J.C. Leiva. 1995. Recent thinning, retreat and flow of Upsala Glacier, Patagonia. Bull. Glacier Res., 13, 11-20.

Skvarca, P., B. Raup and H. de Angelis. 2003. Recent behaviour of Glaciar Upsala, a fast-flowing calving glacier in Lago Argentino, southern Patagonia. Ann. Glaciol., 36, 184-188.

Skvarca, P., R. Naruse and H. de Angelis. 2004. Recent thickening trend of Glaciar Perito Moreno, southern Patagonia. Bull. Glaciol. Res., 21, 45-48.

Takeuchi, Y., R. Naruse and K. Satow. 1995. Characteristics of heat balance and ablation on Moreno and Tyndall glaciers, Patagonia, in the summer 1993/94. Bull. Glacier Res., 13, 45-56. 
Table 1. Measurement locations for 17 March 2002 in the Japanese Profile

\begin{tabular}{lccccc}
\hline & Northing* & Easting* & Height & & Distance \\
& $\mathrm{m}$ & $\mathrm{m}$ & $\mathrm{m}$ h.a.e. & $\mathrm{m}$ & \\
& & & & & \\
& & & & & \\
& $4330000+$ & $610000+$ & & & \\
T1 & 4712.5 & 8831.2 & 567.3 & 585.5 & 281.8070 \\
T2 & 4545.8 & 8448.5 & 611.0 & 956.9 & 267.1858 \\
T3 & 4332.1 & 8054.9 & 632.2 & 1374.3 & 259.0694 \\
T4 & 4097.5 & 7694.4 & 636.7 & 1780.2 & 253.8472 \\
T5 & 3878.7 & 7358.2 & 637.8 & 2167.1 & 250.7621 \\
T6 & 3647.2 & 6975.7 & 636.2 & 2606.2 & 248.7270 \\
T7 & 3392.1 & 6525.1 & 642.1 & 3119.5 & 247.3633 \\
T8 & 3306.4 & 6371.2 & 641.9 & 3294.6 & 247.0175 \\
T9 & 3029.3 & 5781.7 & 634.7 & 3945.6 & 246.6551 \\
T10 & 2803.4 & 5418.3 & 619.7 & 4369.2 & 245.8246 \\
T10P & 2793.7 & 5403.3 & 620.8 & 4386.9 & 245.7892 \\
T11 & 2670.2 & 5150.1 & 629.7 & 4668.4 & 245.6813 \\
T11P & 2670.5 & 5149.9 & 629.8 & 4668.5 & 245.6861 \\
& & & & &
\end{tabular}

*UTM Zone 18 South. "WGS84 ellipsoid. "From Alpha, with azimuth measured clockwise from grid north.

Table 2. Measurement locations for 22 March 2002 in the Boulder Profile

\begin{tabular}{|c|c|c|c|c|c|}
\hline & $\begin{array}{c}\text { Northing* } \\
\text { m }\end{array}$ & $\begin{array}{c}\text { Easting* } \\
\mathrm{m}\end{array}$ & $\begin{array}{l}\text { Height }^{\dagger} \\
\text { m h.a.e. }\end{array}$ & $\begin{array}{c}\text { Distance }^{*} \\
\mathrm{~m}\end{array}$ & $\underset{\circ}{\text { Azimuth }}$ \\
\hline $\mathrm{L} 1^{\S}$ & $\begin{array}{c}4320000+ \\
7680.7\end{array}$ & $\begin{array}{c}610000+ \\
8393.6\end{array}$ & 436.3 & 2204 & 225.9906 \\
\hline L2 & 7847.5 & 8642.6 & 437.8 & 1910 & 224.3993 \\
\hline L3 & 8005.7 & 8898.8 & 439.3 & 1619 & 221.8385 \\
\hline L4 & 8157.3 & 9159.1 & 436.7 & 1336 & 217.8543 \\
\hline L5 & 8335.5 & 9401.2 & 436.1 & 1050 & 213.3826 \\
\hline L6 & 8460.8 & 9618.5 & 433.5 & 833 & 205.6201 \\
\hline L7 & 8589.9 & 9797.3 & 428.5 & 648 & 196.2659 \\
\hline L8 & 8696.8 & 9982.1 & 405.3 & 515 & 179.633 \\
\hline L9\| & 8789.3 & 10127.5 & 386.0 & 448 & 160.6044 \\
\hline
\end{tabular}

*UTM Zone 18 South. "WGS84 ellipsoid. "From Gamma, with azimuth measured clockwise from grid north. ${ }^{\S}$ On medial moraine. "On ice $35 \mathrm{~m}$ from rock margin.

Table 3. Coordinates for rock points

\begin{tabular}{|c|c|c|c|c|}
\hline & Northing* & Easting* & Height $^{\dagger}$ & $\begin{array}{c}\text { Eleva- } \\
\text { tion }\end{array}$ \\
\hline & $\mathrm{m}$ & $\mathrm{m}$ & mh.a.e. & ma.s.l. \\
\hline Alpha & $4334592.7 \pm 0.2$ & $619404.3 \pm 0.2$ & $687.1 \pm 0.2$ & $677.6^{\ddagger}$ \\
\hline Beta & $4334753.5 \pm 0.2$ & $619295.0 \pm 0.2$ & $647.4 \pm 0.2$ & $637.8^{\S}$ \\
\hline Gamma & $4329211.9 \pm 2.5$ & $619978.8 \pm 2.5$ & $433.6 \pm 2.5$ & \\
\hline
\end{tabular}

*UTM Zone 18 South. "WGS84 ellipsoid. *Assumed by Kadota and others (1992) and Nishida and others (1995). ${ }^{\S}$ Taken to be $659 \mathrm{~m}$ by Naruse and others (1987).
Truffer, M., R.J. Motyka, W.D. Harrison, K.A. Echelmeyer, B. Fisk and S. Tulaczyk. 1999. Subglacial drilling at Black Rapids Glacier, Alaska, USA: drilling method and sample descriptions. J. Glaciol., 45(151), 495-505.

Warren, C.R. and M.P. Kirkbride. 2003. Calving speed and climatic sensitivity of New Zealand lake-calving glaciers. Ann. Glaciol., 36, 173-178.

Warren, C., D. Benn, V. Winchester and S. Harrison. 2001. Buoyancy-driven lacustrine calving, Glaciar Nef, Chilean Patagonia. J. Glaciol., 47(156), 135-146. Erratum: 47(157), 348.

Weertman, J. 1961. Stability of ice-age ice sheets. J. Geophys. Res., 66(11), 3783-3792.

Zumberge, J.F., M.B. Heflin, D.C. Jefferson, M.M. Watkins and F.H. Webb. 1997. Precise point positioning for the efficient and robust analysis of GPS data from large networks. J. Geophys. Res., 102(B3), 5005-5017.

\section{APPENDIX SURVEY AND DATUM RECONCILIATION}

In 2000 and 2002 our procedure was based on fast-static, differential GPS using a fixed base station (Trimble 4000 SE in 2000 and Trimble 5700 in 2002) near our camp about $2 \mathrm{~km}$ east of the Japanese Profile's east end and a rover on the glacier (Trimble 4000 SE in 2000 and Trimble Geoexplorer I in 2002) guided to within $10 \mathrm{~m}$ of earlier measurement locations by hand-held GPS. The GPS location of the base station for each year was determined with Auto Gipsy point positioning strategy (Zumberge and others, 1997) using the JPL GIPSY/OASIS II software applied to multi-hour recording intervals. Formal standard errors were calculated to be at millimeter level in both horizontal and vertical directions. Actual errors are commonly assumed to be up to three times larger. The locations measured on the glacier were determined by differential GPS using occupation periods of 10 or more minutes with baseline precision for elevation difference better than $0.01 \mathrm{~m}$ in 2000 and typically better than $0.2 \mathrm{~m}$, but sometimes as bad as $0.6 \mathrm{~m}$ in 2002 .

Table 1 gives the locations of the measurement points for 2002 in the Japanese Profile, which are close to marker locations and along the same line as that occupied in 1990 and 1993 by Nishida and others (1995) and our occupations in 2000. Coordinates are given to the nearest $0.1 \mathrm{~m}$ for measurements with accuracy of $0.2 \mathrm{~m}$ or less and to the nearest $1 \mathrm{~m}$ for other measurements. In all cases, survey accuracy of heights is considerably better than the uncertainty associated with surface roughness and short-term variability in the lowering rate from weather.

Measurements in 2002 for the Boulder Profile proceeded toward the center from an area called Gamma (Table 3) near the edge of the glacier. Table 2 gives coordinates for measured points on the glacier.

To relate our 2000 and 2002 GPS measurements to earlier surveying and map information tied to Alpha and Beta, we determined GPS coordinates for Alpha and Beta in the same manner as surface points, with the results given in Table 3. The height difference between Alpha and Beta so determined $(39.7 \mathrm{~m})$ is closely consistent with that determined by theodolite and distance ranging in 1999 (39.8 m), as found by $\mathrm{H}$. Lange (personal communication, 1999). We assume that the elevations published for surface markers in 1985 (Naruse and others, 1987, fig. 5), 1990 (Kadota and others, 1992, fig. 3) and 1993 (Nishida and others, 1995, fig. 3) are based on an elevation of Beta taken to be $659 \mathrm{~m}$ (Naruse and others, 1987, p.137). We adjust these surface elevation 
measurements to the WGS84 ellipsoid datum (Fig. 5) by accounting for the difference in elevation between Alpha and Beta $(39.8 \mathrm{~m})$, the elevation of Alpha $(677.6 \mathrm{~m})$ assumed in the Japanese publications and the height of Alpha above the ellipsoid determined from GPS in 2002 (687.1 m)
(Table 3). The datum for the 1975 maps (Kadota and others, 1992) can be similarly adjusted from the assumed height and GPS-determined ellipsoid height for Alpha. We choose to use WGS84 ellipsoid for datum consistently for all results, since it is standard for GPS.

MS received 22 October 2003 and accepted in revised form 16 January 2005 